\title{
Brand Identity Design of "Favorlt" Skin Care Products
}

\section{${ }_{1 *}$ Rudy Farid and ${ }^{2}$ Belinda Ghassani}

Graphic Design Study Program, Fakultas DKV, Universitas Widyatama, Indonesia

1*rudy.farid@widyatama.ac.id, ${ }^{2}$ ghassani_belinda@yahoo.co.id

Article History: Received:11 January 2021; Accepted: 27 February 2021; Published online: 5 April 2021

\begin{abstract}
Abtract: The beauty clinic business and skin care products are currently in great demand by the people of Indonesia, especially women. Skin care is no longer a tertiary necessity but has become a way of life in modern times. This increasing trend is also due to the influence of influencers and celebrities from within the country and from abroad who share their lifestyle with the people in Indonesia, including the world of skin care. Through various e-commerce applications or commonly called online shopping, imported products are now no longer difficult to find in Indonesia. So it cannot be denied that the world of skin care is a growing and potential market in Indonesia. CV Blessindo Prioriti Abadi is one of the distributors of beauty products and skin care which is well known by beauty clinic clinics in Indonesia. In 2019, they launched a skin care product with their own brand called "FavorLT" which began to be sold independently through a website called skinny.id. This product requires a systematic and attractive visual identity design so that it can attract the interest of skin care product enthusiasts and compete with existing skin care products in the Indonesian market.
\end{abstract}

Keywords: Beauty products, skin care, brand identity

\section{Introduction}

The beauty clinic business and skin care products still promise big profits. The market is wide spread, no longer limited by gender, because everyone wants to look perfect. Several other factors influence the consumption of skin care products, for example per capita income, promotion, digitization and lifestyle changes. In addition to perfecting the appearance, urban conditions which are now full of pollution are also one of the factors in increasing public interest in intensive skin care.

According to research from SAC (Science, Art, Communication) Indonesia, skin care is the largest market for cosmetics and personal care throughout 2018. The skin care market earned US \$2,022 million in the cosmetics and personal care market, which was US \$ 5,502 million. Reporting from Euromonitor International entitled "The future of skin care", Indonesia will be the second largest contributor to the growth of skin care / skin care. In addition, the easy access of the public to beauty products from abroad through e-commerce, and the rise of beauty blogger influencers also have an effect on attracting the public. In 2018 there were more than 760 companies engaged in cosmetics. This year, according to the Ministry of Industry, the Indonesian cosmetics industry is estimated to increase by around 9 percent, and is projected to continue to grow by 7.2 percent per year until 2021.

Blessindo Prioriti Abadi is a manufacturer of personal care products that have been registered with BPOM for skin care and body care.

This company was founded in late 2014, by Jahja B. Soenarjo with the support of expert doctors and a development team experienced in serving the needs of various products for aesthetic doctors, aesthetic clinics, specialists, special salons and spas, as well as direct sales networks.

In 2019, Blessindo Prioriti Abadi began launching the latest skin care products which will be sold online under the brand "FavorLT".

However, "FavorLT" products that are readily available online, have some visual identity and packaging design issues. Such as, the same color and labels on several different products, layout that has no system or inconsistencies.

The similarity in design of various different products becomes an obstacle in the packaging process. And as a new brand, inconsistencies in visual appearance will complicate the process of introducing products to consumers. 
Based on this background, the researchers are interested in designing the "FavorLT" brand identity and the application of identity design to packaging design and various other media.

\section{Literature Review}

\subsubsection{Visual communication design}

The design comes from the Latin designare. In English it is called design or in French it is called dessiner which means to describe or can mean design. In the Big Indonesian Dictionary (2001), "design" or "design" means 1) framework; 2) design. According to Archer, design is a field of human skills, knowledge and experience that reflects its attachment to the appreciation and adaptation of its environment in terms of spiritual and material needs (Sachari, 1986). In particular, design is associated with configuration, composition, meaning, value and man-made phenomena. According to Kusmiati (1999), composition is considered as an organization of design elements by strictly following certain principles. The design must have an aesthetic value, because aesthetic value can make a design attractive. In the use of various visual elements such as lines, shapes, colors, textures, and spaces, a good design needs to uphold design principles such as unity, balance, rhythm, proportion and contrast.

Meanwhile, visual communication consists of communication and visual words. According to Susanto (1997), communication means giving information. Communication means sending and receiving messages or news between two or more people so that the intended message can be understood (KBBI, 2001). In addition, communication is a process where an idea is transferred or conveyed from a source or someone to a recipient with the intention of changing their perspective and attitude.

Today, visual communication design or what was previously known as graphic design, is a work of art that is technology-intensive, which has a comprehensive impact on society as the target audience. Because with a good design, information can be easier to understand and memorable for the public.

Visual communication design is the science that develops a form of visual communication language in the form of processing messages for social or commercial purposes from individuals or groups aimed at other individuals or groups (http://www.itb.ac.id/, 2020). So, it can be concluded that visual communication design is the art of conveying messages in visual language conveyed through the media, so that messages and ideas can be well received by communication targets.

\subsubsection{Brand and branding}

According to Alina Wheeler in her book entitled "Designing Brand Identity: An Essential Guide for the Whole Branding Team" explains that a good branding program can make a product stand out in an already saturated market. With good branding, people will know, trust and like a brand.

In the book, it is also explained that a brand has 3 main functions, namely as follows:

a. Navigation

Brands help consumers to choose from a wide and confusing variety of choices.

b. Reassurance

Brands communicate intrinsically about the quality of a product or service and assure customers that they are making the right choice.

c. Engagement

"Brands use different images, languages, and associations to encourage customers to identify brands." - David Haigh, CEO, Brand Finance.

\subsubsection{Brand identity}




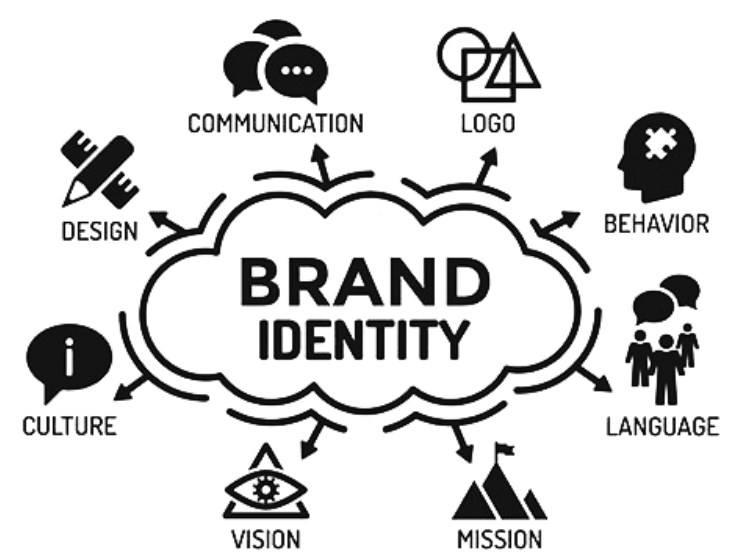

Figure 1. Illustration of elements of brand identity (https://gentiyus.com/brand-identity-design/)

Alina Wheeler's book entitled "Designing Brand Identity: An Essential Guide for the Whole Branding Team" explains that Brand Identity is a visual form that is real and attractive to our senses. That is, we can see it, touch it, hold it, listen to it and watch it if there is movement. A good Brand Identity will trigger recognition, strengthen differentiation, and make a big idea or meaning accessible to customers. Brand Identity takes a variety of different elements and unites them into the entire system as a single unit.

\subsubsection{Packaging design}

a. Definitions

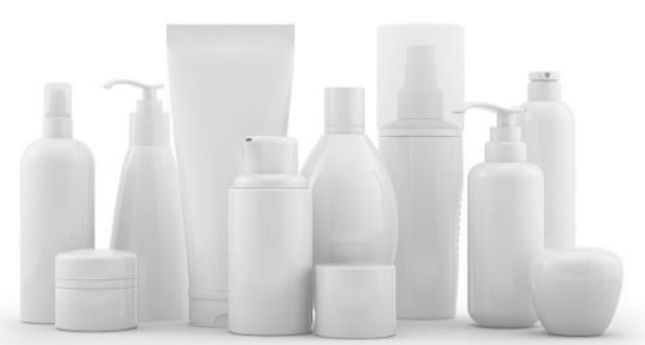

Figure 2. Examples of cosmetic packaging (https://packagingoptionsdirect.com/best-cosmetics-packaging-andtypes)

1. According to the Oxford dictionary, packaging means a group of items that are packaged or wrapped together (bundle of things wrapped up together for carrying.)

2. According to Wikipedia, packaging is a science, art and technology that aims to protect products when they are sent, stored or sold.

3. According to Didit Widiatmoko (2007), packaging is essentially a human effort to collect something messy into a container and protect it from the weather.

b. Packaging Design History

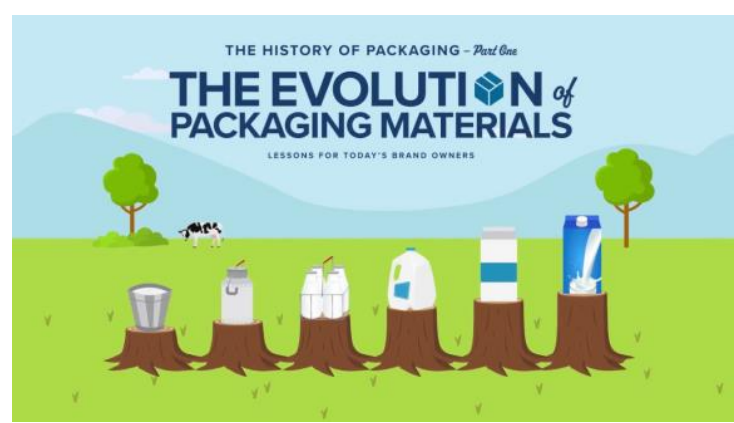

Figure 3. Examples of packaging evolution (https://www.youtube.com/watch?v=xz9UM9ZVvXY)

Packaging first appeared in the 19th century as a new invention, which allowed manufacturers to supply their products to stores fresh and in good condition. At that time, the function of packaging was still simple, but 
important and basic, namely as a wrapper and protector, so that the product can last a long time and remain intact on the store shelves.

c. Packaging Functions by Mendiola (2007)

1. Protection function

Good packaging must be able to provide physical protection for the product.

2. The function of grouping, placing and storing, good packaging must be able to classify the material and efficiency if the material is stacked or carried in large quantities.

3. Security Functions

Good safety should use materials that are safe for consumers and do not contaminate the contents of the product chemically.

4. Information Functions

Good packaging should be able to provide appropriate information to consumers both verbally and non-verbally. 5. Physical convenience function

Good packaging should pay attention to the shape of the packaging (packaging, display, until finally it reaches the consumer).

6. Marketing function

Good packaging should have a good appearance graphically, so that it looks eye-catching to pick up, and has appeal to everyone.

\subsection{Logo}

The logo comes from Greek, namely Logos which means words, thoughts, speech, reason. Initially, what was popular first was the term logotype, which was defined as the writing of the name of the entity that was specifically designed using lettering techniques or using certain types of letters. In its development, the logo is increasingly unique because there are additional image elements in it. Among them the logo functions are as follows:

1. As an identity to differentiate from other identities.

2. As a sign of ownership to distinguish ours from other people's.

3. A sign of quality assurance.

4. Prevent imitation or piracy.

In general, logos are symbols of visual identity. In the opinion of John Murphy and Michael Rowe, logos are divided into several types, namely:

1. Name-Only Logo

Is a logo that is taken from a name using typography and a special visual style with the aim of reinforcing differences and impressions.

2. Name / Symbol Logo

Is a logo which is a combination of a brand name with a certain visual form.

3. Initial Letter Logo

Is a logo that uses the initial letters (initials) of the product or company name and makes it the main element of the logo.

4. Pictorial Names Logo

Is a logo that uses the product or company name as an important component of the logo style. The whole logo has a special style

5. Associative Logo

Is a free-standing logo that does not contain the product or company name but has direct association with the name, product or area of activity?

6. Allusive Logo

Is a figurative logo. Examples include the Mercedes Benz logo, from the triangular star shape which represents the car's steering system and the Shopee logo in the form of a shopping cart which represents a place to shop.

7. Abstract Logo

Is a logo that can create various impressions that are influenced by the understanding power of consumers. This happens because the shape of this logo is very abstract.

According to Surianto Rustan, S.sn in his book "Designing a Logo", a good logo must have the following criteria:

1. Unique, that is, from its new, unusual shape, attracts attention and is different from other logos.

2. Simple, that is easy to see, easy to recognize, and easy to remember. 
3. Flexible, which is easy to apply to various media and materials, easy to develop, and easy to assemble and assemble without losing its identity.

\subsection{Redesign}

The word redesign is adopted from English redesign which consists of two elements, namely re which means to repeat or return and design which means to plan or form. So, the word redesign means to re-plan or reshape something that already exists (en.wiktionary.org/wiki/redesign). Some redesign definitions from several sources:

- According to the American Heritage Dictionary (2006), "redesign means to make a revision in the appearance or function of".

- According to Collins English Dictionary (2009), "redesign is to change the design of (something)", which can be interpreted as changing the design of (something).

- According to Salim's Ninth Collegiate English-Indonesian Dictionary (2000), redesign means redesigning.

Redesign is changing the design or redesign, changing the existing design and starting the design with a new idea, resulting in changes in appearance and function. According to Catharine Fishel in the book Logo Lounge, there are five main reasons why companies are redesigning them, namely:

a. Repositioning

Redesign carried out in the context of developing or improving the company's position in the eyes of the audience.

b. Modernizing

Redesign done so that a company is not left behind in the competition. And in order to update or refresh the appearance and keep up with the changing times.

c. Managing Change

Whether a company sees change as a bad or a good thing, change is sure to exist. If a company refuses to make changes, the company will continue to retreat.

d. Promoting Growth

For companies that want to grow from small to large companies, or for large companies that want their existence to be increasingly recognized, promoting themselves through a new identity is a bold and tactical step.

e. Starting Over

Sometimes the old corporate identity can no longer be saved, in such cases a new identity is needed.

In this case, the "FavorLT" skin care product requires a logo redesign in its application to various visual media so that it is more systematic, in line with the target market, and is more widely known by the public.

\section{Results and Discussion}

\subsection{Design Concepts}

CV. Blessindo Prioriti Abadi, has several superior skin care products with their respective brands namely Favor, Skin Rx, Optima, and Dermacell.

Previously, Favor products were included in Blessindo's superior skin care products, but after the development of the previous composition, the brand "FavorLT" was created for skin care products, which are specifically marketed online (e-commerce). Currently the product is still being marketed through the company's "skinny.id" website.

The "FavorLT" product series has 2 types of variants, namely a series for acne-prone skin and a series for normal skin. Each product series has three types of products, namely Facial Wash, Toner, and Sunscreen.

\subsection{1. "FavorLT" existing logo}

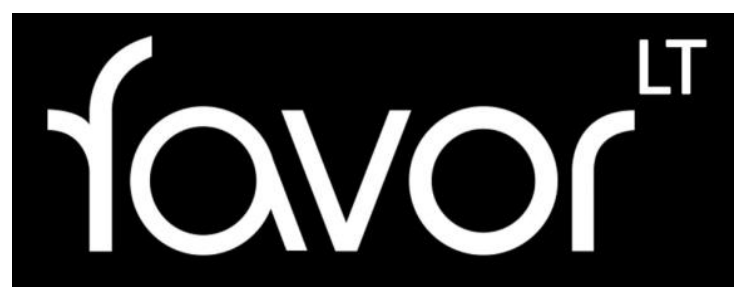


Figure 4. FavorLT logo

This logo is the same logo and product name as the product that has been marketed by CV. Blessindo Abadi. However, the difference lies in the back word "LT" which means "Limited" or Limited / Exclusive. In the interview session with the owner, Mr. Jahja B Soenarjo, he explained that the name "Favor" is used the same as the meaning of kindness / kindness / blessing, which is still related to the company name, namely "Blessindo". This product is expected to provide "goodness / blessing" to the customer's skin with a formula that is safe and in accordance with customer needs. This logo uses a typographic concept in a modern and minimalist style. In its application, the color used is white.

\subsection{2. "FavorLT" existing packaging design}
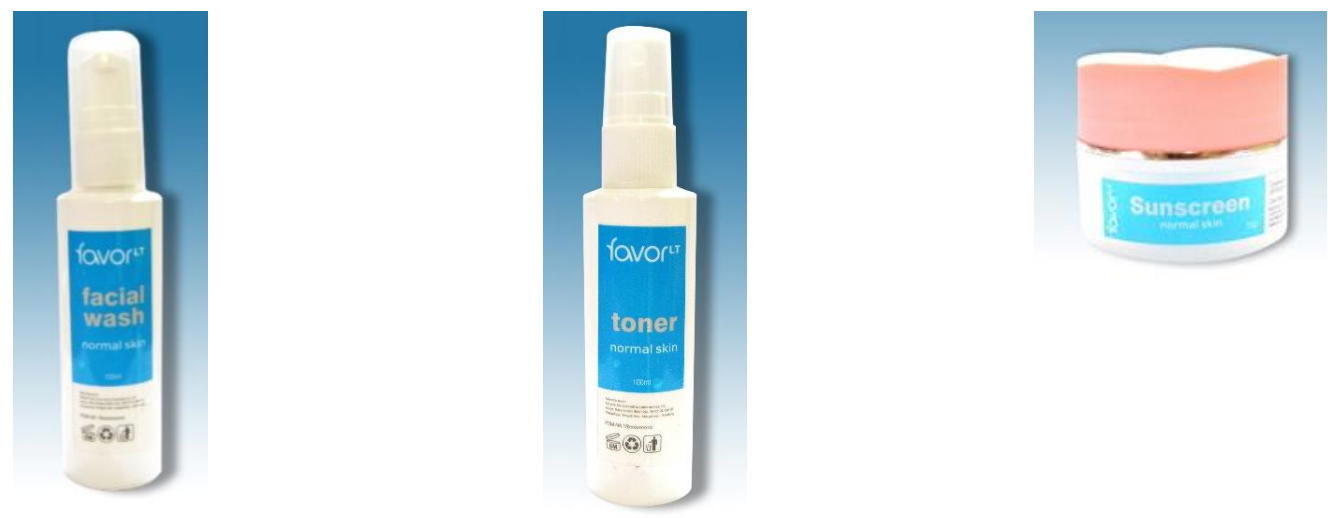

Figure 5. Normal skin variant of FavorLT products (www.skinny.id/id)
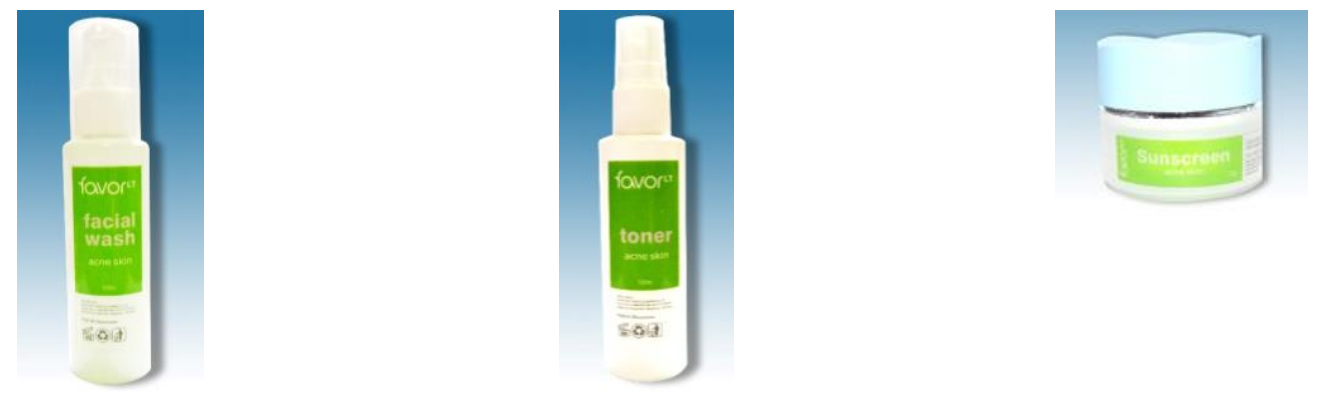

Figure 6. FavorLT products of acne skin variants (www.skinny.id/id)

The label on the product packaging looks very simple, unattractive, has no distinguishing features and incomplete information about the product; such as ingredients, expiration date and barcode.

\subsection{3. "FavorLT" marketing}

Currently, product marketing is still limited to being marketed through an independent website called "skinny.id/id".

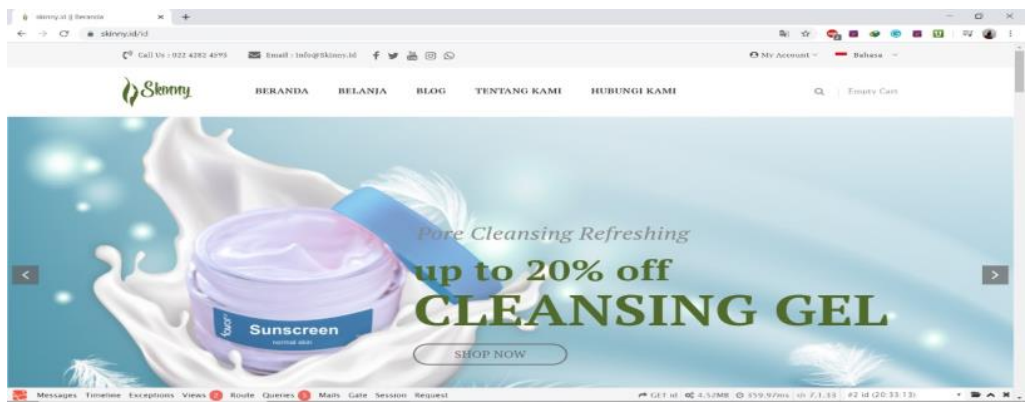




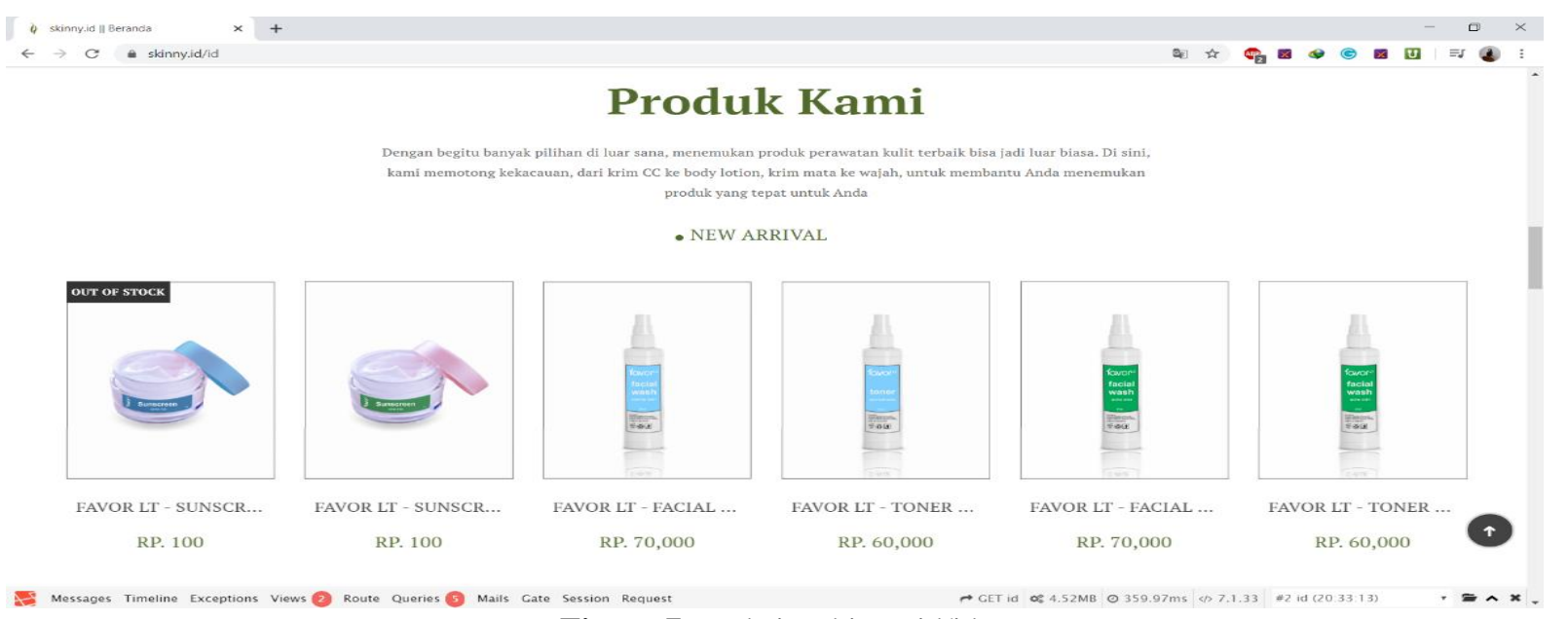

Figure 7. Website skinny.id/id

Some product images on the website are not the same as the product being marketed. The label design was inconsistent and unsystematic. very visible on the product image on the website, is the color that does not match the original product and there is an additional border line on the label that is not on the original product.

\subsection{Design concept}

\subsubsection{Brand name and logo}

The author, proposes a new name for FavorLT products. This new brand name aims to build differentiation and build a good impression / perception.

The main idea in the redesign of the "Veluna" logo was to develop the letter "V" combined with leaves for a natural look. Along with the mentoring process by lecturers, the logo develops into an allusive logo. The concept of logos and typography is designed in such a way as to suit the specificity of the product, and in order to create a natural, fresh, dynamic and modern impression.

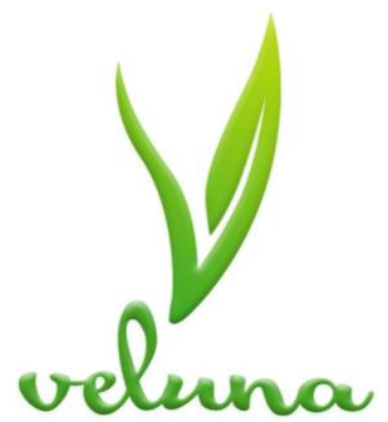

Figure 8. The Veluna logo

a. The logo consists of two components namely:

1) The V image and the leaf-like tip of the letter represent that this product uses natural materials.

2) Logotype uses hand writing font, for a natural and personal impression.

a. Graphic Standard Manual

1) Color Guide 


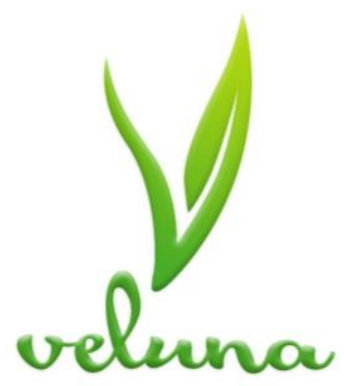

Figure 9. Veluna logo

$$
\begin{aligned}
\mathrm{C}=77 \% \mathrm{M} & =9 \% \mathrm{Y}=100 \% \mathrm{~K}=1 \% \\
\mathrm{C}=33 \% \mathrm{M}=0 \% \mathrm{Y} & =100 \% \mathrm{~K}=0 \%
\end{aligned}
$$

2) Logo Configuration

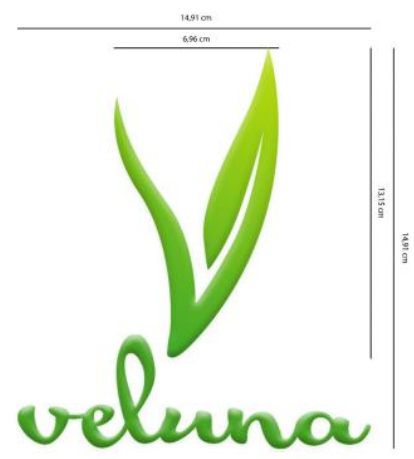

Figure 10. Veluna logo configuration

3) Grid Sytem

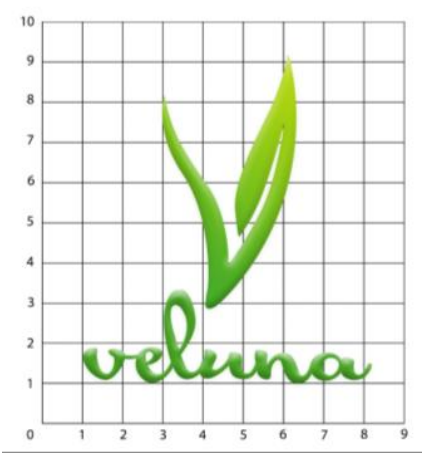

Figure 11. Veluna logo grid sytem

4) Typography

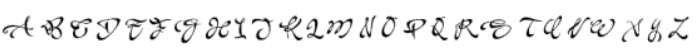

$$
\begin{aligned}
& \text { abedefghijklmnopqustuow xyz }
\end{aligned}
$$

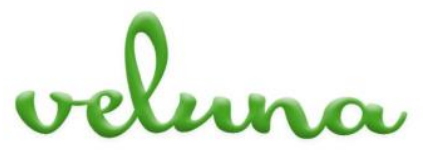

Figure 12. The inscription of the Veluna logo

The typeface used in the Veluna logo is Acryle Script.

\subsubsection{Color}

Color is an important element to build a certain mood or atmosphere. Color is also a means of emphasizing accents. 
The colors used in this design include:

Green

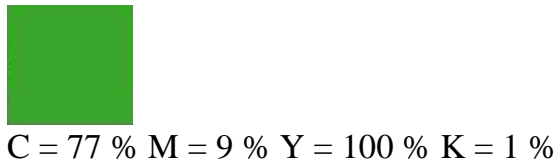

Chartreuse

$\mathrm{C}=33 \% \mathrm{M}=0 \% \mathrm{Y}=100 \% \mathrm{~K}=0 \%$

Pale Yellow

$\mathrm{C}=4 \% \mathrm{M}=5 \% \mathrm{Y}=44 \% \quad \mathrm{~K}=0 \%$

Yellow

$\mathrm{C}=8 \% \mathrm{M}=17 \% \mathrm{Y}=97 \% \mathrm{~K}=0 \%$

Dark Grey

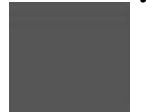

$\mathrm{C}=64 \% \mathrm{M}=56 \% \mathrm{Y}=55 \% \mathrm{~K}=30 \%$

Green

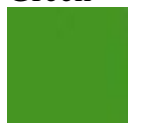

$\mathrm{C}=76 \% \mathrm{M}=18 \% \mathrm{Y}=100 \% \mathrm{~K}=4 \%$

Pale Green

$\mathrm{C}=11 \% \mathrm{M}=0 \% \mathrm{Y}=22 \% \mathrm{~K}=0 \%$

Creme

$\mathrm{C}=13 \% \mathrm{M}=8 \% \mathrm{Y}=22 \% \mathrm{~K}=0 \%$

Light Grey

$\mathrm{C}=5 \% \mathrm{M}=3 \% \mathrm{Y}=3 \% \mathrm{~K}=0 \%$

\subsubsection{Typography}

Typography is an important factor in product rebranding. Typography acts as a message and messenger. The typography or typeface used is adjusted to existing concepts. 


\section{Myriad Pro \\ ABCDEFGHIJKLMNOPQRSTUVWXYZ \\ Abcdefghijklmnopqrstuvwxyz}

\subsection{Design results}

\subsubsection{Product labels}

Bottle product labels for Facial Wash and Toner types use sticker paper media with a length of $12 \mathrm{~cm}$ and a width of $8 \mathrm{~cm}$, while for sunscreen types that use pots, use sticker paper media with a length of $2 \mathrm{~cm}$ and a width of $10 \mathrm{~cm}$.

a. Veluna Facial Wash for Acne Skin Label

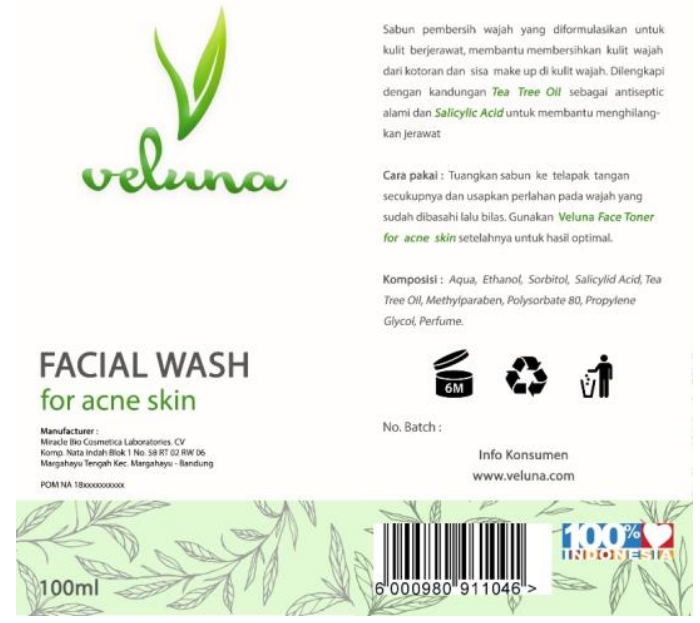

Figure 13. Label facial wash Veluna for acne skin

This label will be used in Veluna facial wash for acne skin products. We use a simple layout that divides the 2 areas of this label. This layout uses a natural, clean, minimalist and elegant concept but is still informative. With a plain background, the writer wants to create a clean impression. We use a little ornament from the simple illustration of "tea tree" leaves as a differentiator from this "Veluna" skin care product variant.

b. Label Veluna Facial Wash for Normal Skin

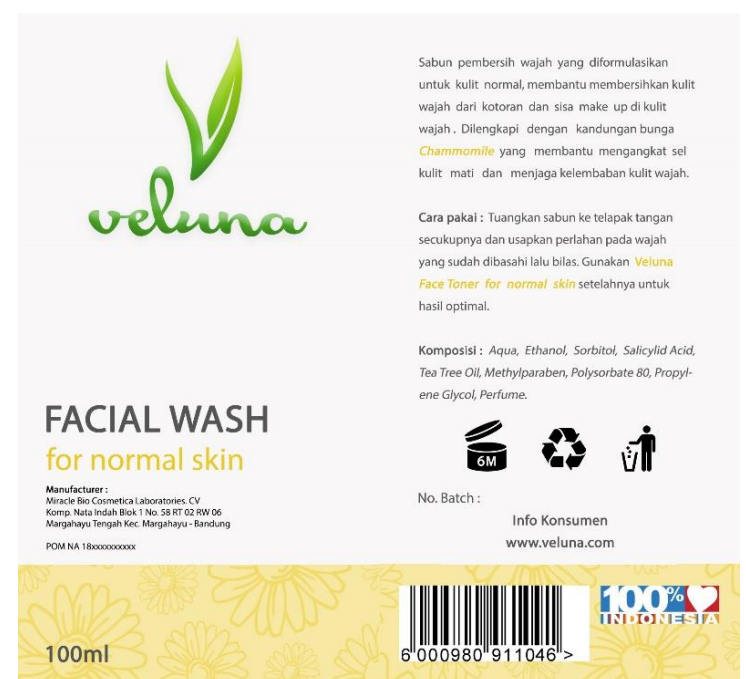

Figure 14. Label facial wash Veluna for normal skin

This label will be used on Veluna facial wash products for normal skin. We use the same layout as the previous labels. For the facial wash variant, we use a plain background to reflect a clean impression so that 
customers can get the same feeling as when washing their face. This variant uses a simple illustration of chamomile flowers, which is one of the superior compositions in Veluna skin care products for normal skin.

c. Label Veluna Toner for Acne Skin

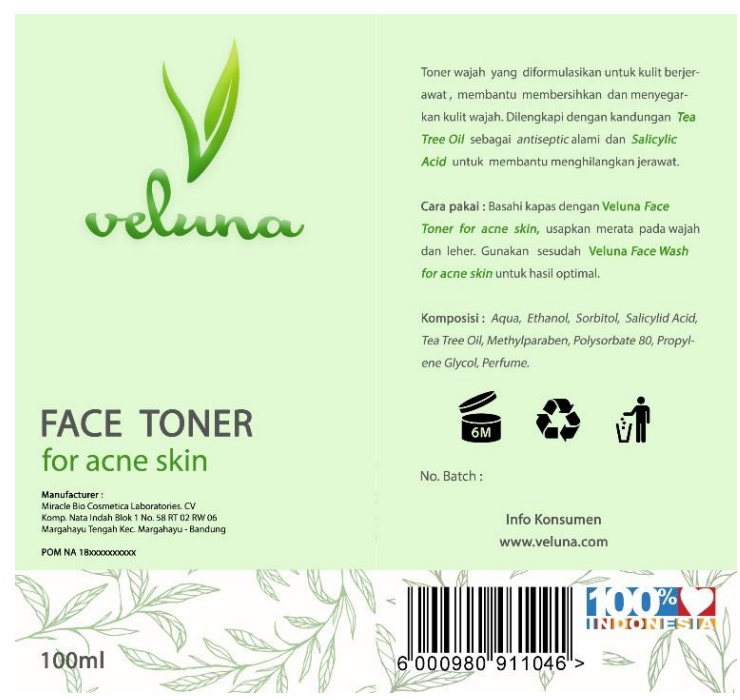

Figure 15. Label toner Veluna for acne skin

This label uses the same concept as the facial wash variant, but uses a different background color and contrast so it is easy to distinguish if it is installed on the same display.

d. Label Veluna Toner for Normal Skin

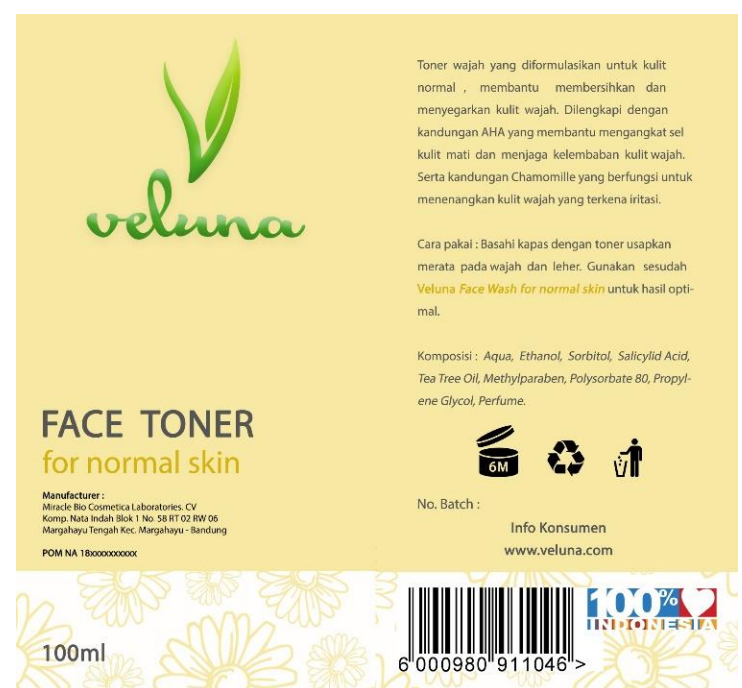

Figure 16. Label toner Veluna for normal skin

This label uses the same concept as the facial wash variant, but uses a different background color and contrast so it is easy to distinguish if it is installed on the same display.

e. Veluna Sunscreen for Acne Skin Label

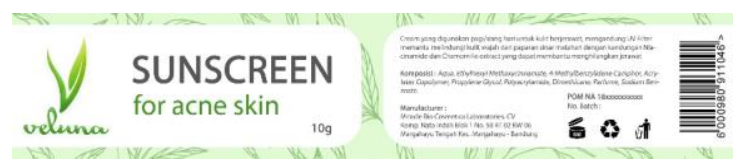

Figure 17. Label sunscreen Veluna for acne skin

This label uses the same concept as the facial wash variant, but the illustration pattern is used as a background and contrast so it is easy to read even though the printed text is smaller than the facial wash variant. 


\section{f. Veluna Sunscreen for Normal Skin}

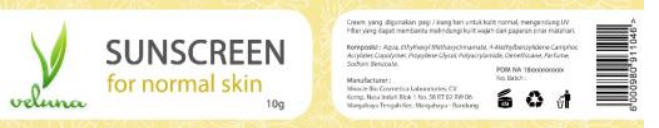

Figure 18. Label sunscreen Veluna for normal skin

This label uses the same concept as the facial wash variant, but the illustration pattern is used as a background and contrast so it is easy to read even though the printed text is smaller than the facial wash variant.

\subsubsection{Product packaging design}

Packaging products for bottles and pots for all types of variants use white kraft paper media with the dimensions of the packaging size $4 \mathrm{~cm}$ long, $4 \mathrm{~cm}$ wide and $15 \mathrm{~cm}$ high, while for the type of Sunscreen the size is $6 \mathrm{~cm}$ long, $6 \mathrm{~cm}$ wide and $4 \mathrm{~cm}$ high.

a. Packaging Veluna Facial Wash for Acne Skin

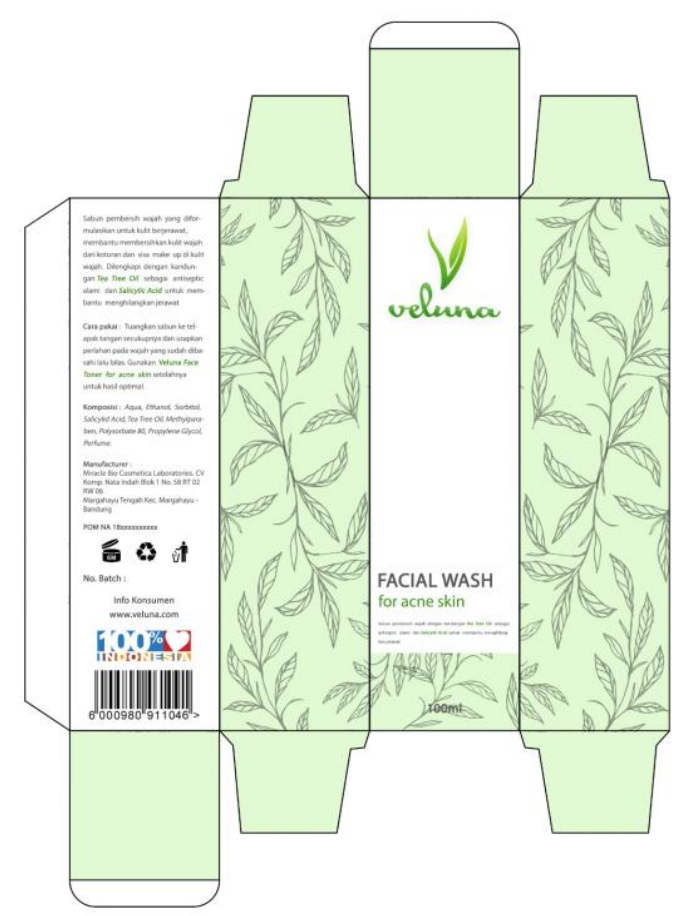

Figure 19. Packaging Veluna facial wash for acne skin

The packaging concept is still the same as the product label concept, but the use of illustrations on the packaging is reproduced for beauty and differentiation between product variants and adding a layout area with a plain background so that product information can be read properly.

b. Packaging Veluna Facial Wash for Normal Skin 


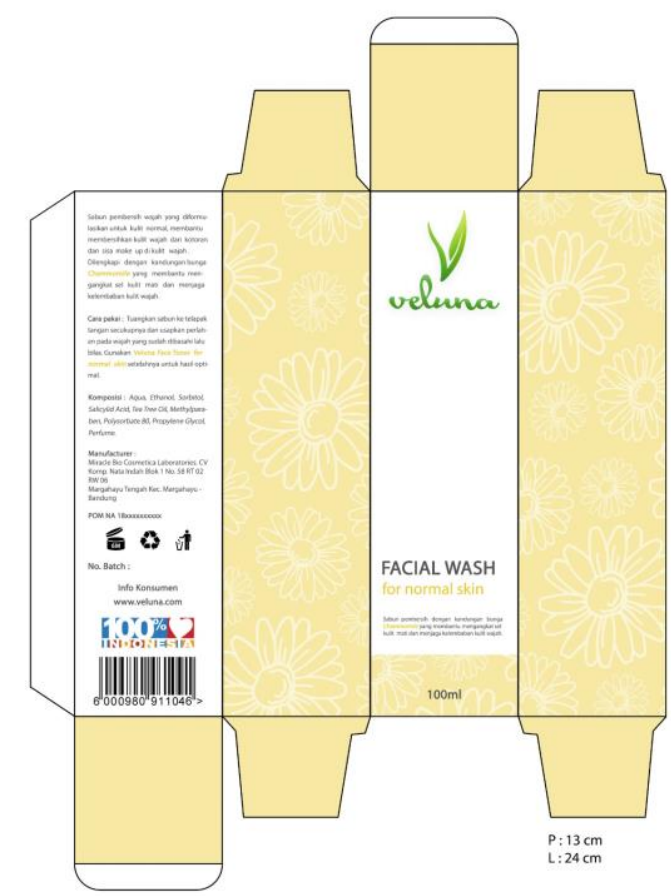

Figure 20. Packaging Dus Veluna facial wash for normal skin c. Packaging Veluna Toner for Acne Skin

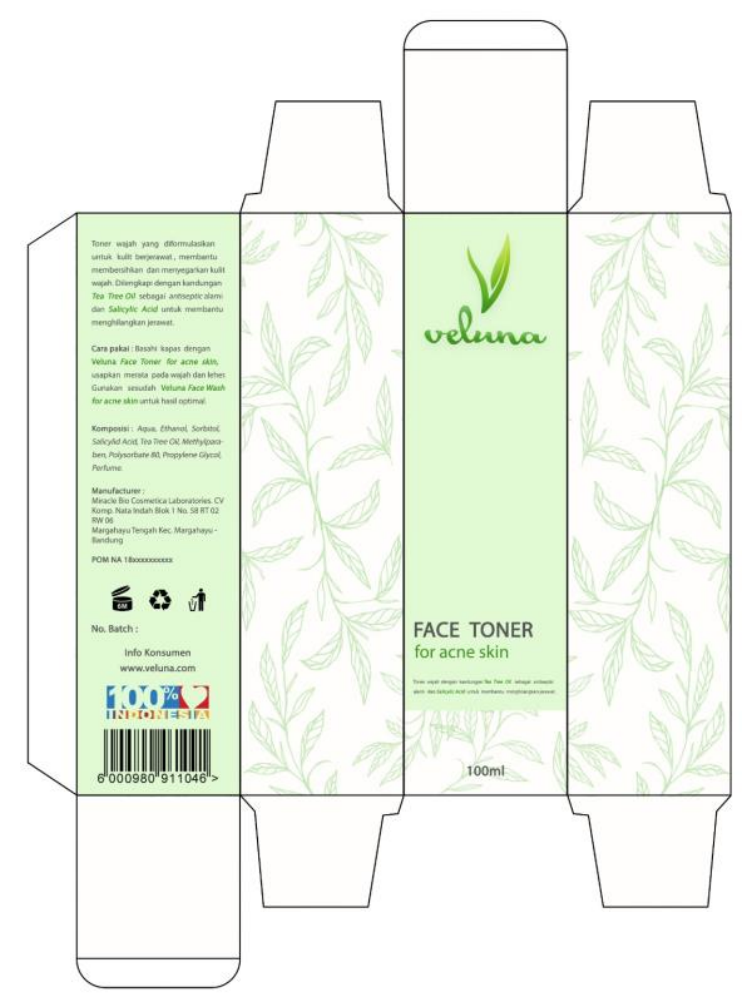

Figure 20. Packaging Dus Veluna toner for acne skin

d. Packaging Veluna Toner for Normal Skin 


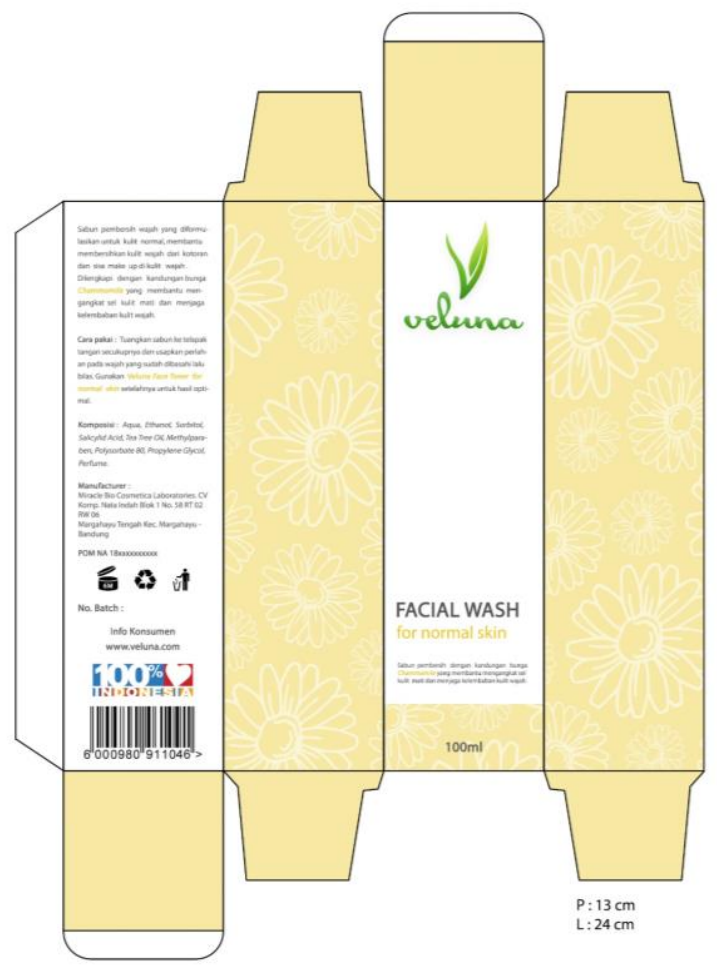

Figure 21. Packaging Dus Toner Veluna for normal skin

e. Packaging Veluna Sunscreen for Acne Skin

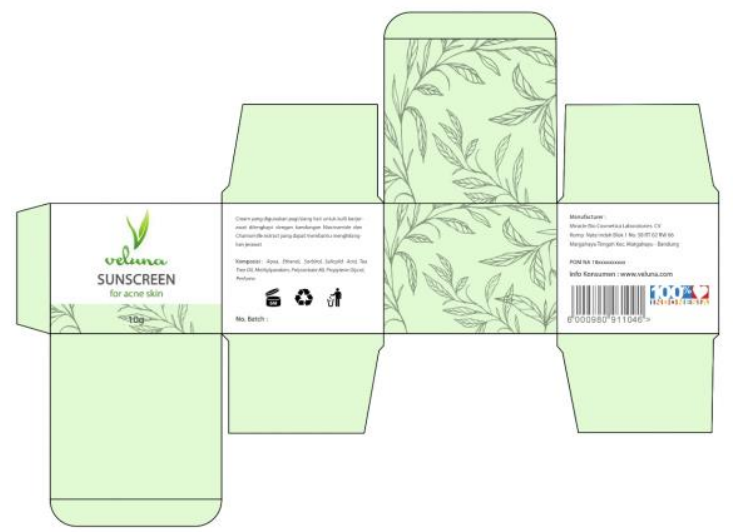

Figure 22. Packaging Dus Sunscreen Veluna for acne skin

The packaging concept is still the same as the product label concept, but the use of illustrations on the packaging is reproduced for beauty and differentiation between product variants and adding a layout area with a plain background so that product information can be read properly.

f. Packaging Veluna Sunscreen for Normal Skin 


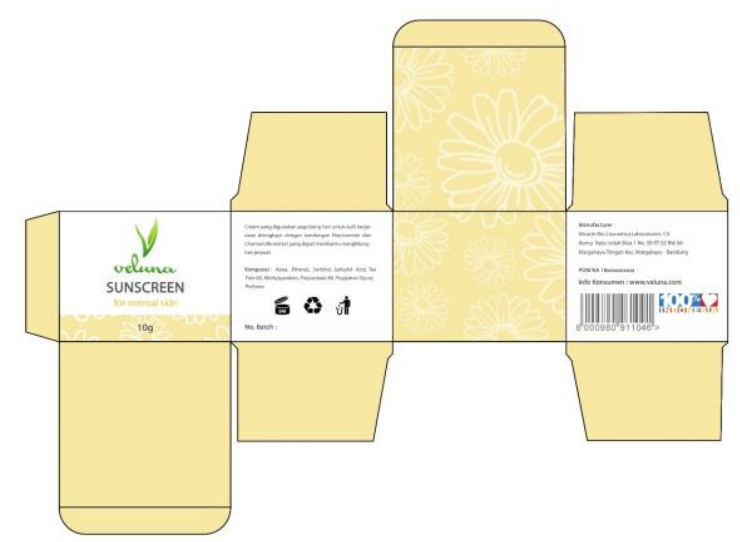

Figure 23. Sunscreen Veluna for normal skin

\subsubsection{Brochure design}

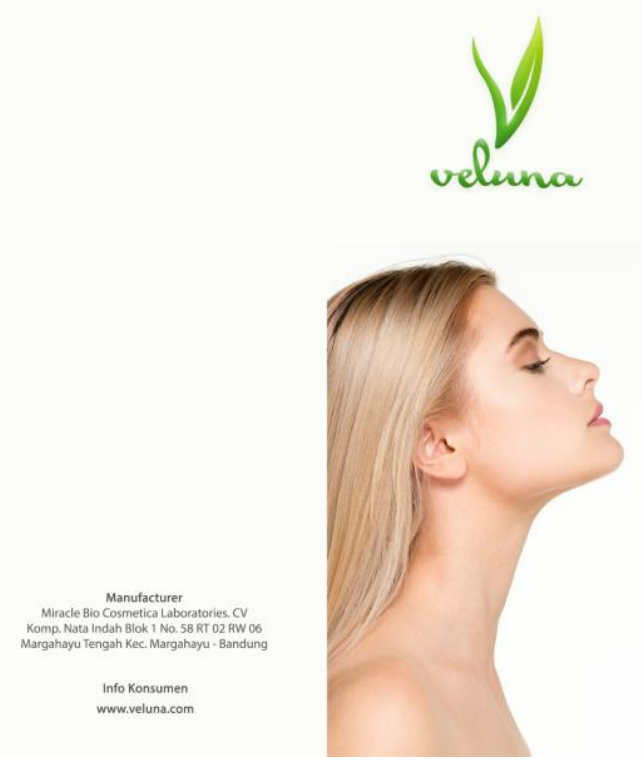

Figure 24. Brochure front page

The brochure concept is adjusted with labels and packaging design, that is natural, minimalist, elegant and clean. For the front view brochure, we included a photo of the skin care model with a logo to make it look minimalist and elegant. The use of a white background also gives a clean and natural impression. Match with the superior content of the product. 


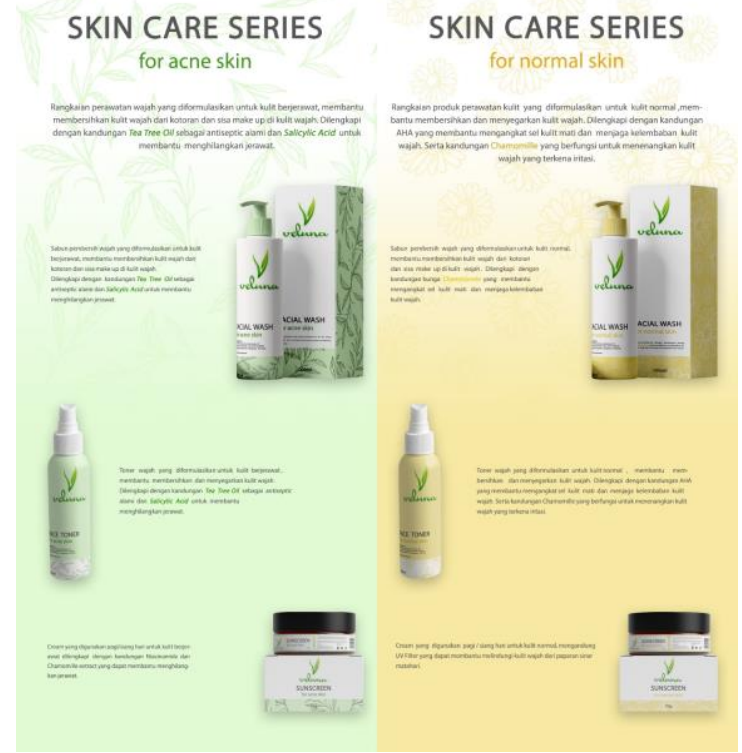

Figure 25. Brochure design

In the content section, we divide 2 areas for each variant so that it is easy to understand.

\subsubsection{E-commerce media}

Media promotion in e-commerce is very necessary, especially when product marketing is done via ecommerce. We make design elements that are usually used in e-commerce, namely, website banners and images of products that are sold containing information about the product.

a. Website Banner Veluna Skin Care for Acne Skin

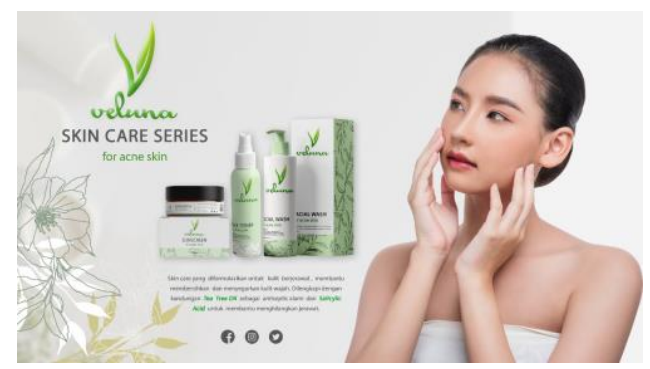

Figur 26. Website banner Veluna skin care for acne skin

In this website banner design, we still apply the existing concept by adding minimalist and natural illustrations to strengthen the brand image on the website.

b. Website Banner Veluna Skin Care for Normal Skin

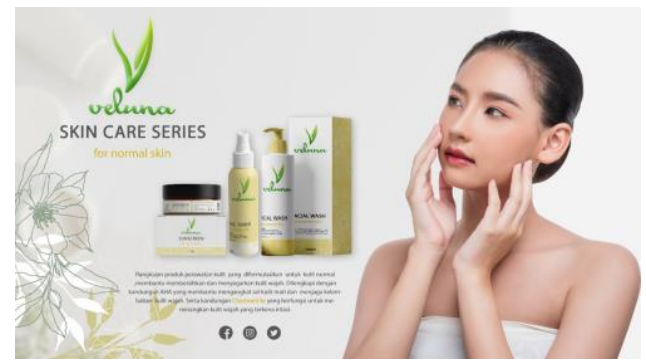

Figure 27. Website banner Veluna skin care for normal skin

In this website banner design, I still apply the existing concept by adding minimalist and natural illustrations to strengthen the brand image on the website. 
We make the same layout for all products with a background that matches the website banner design so that the product becomes the main focus when viewed on an e-commerce website. The second slide contains a brief description of the Veluna product.

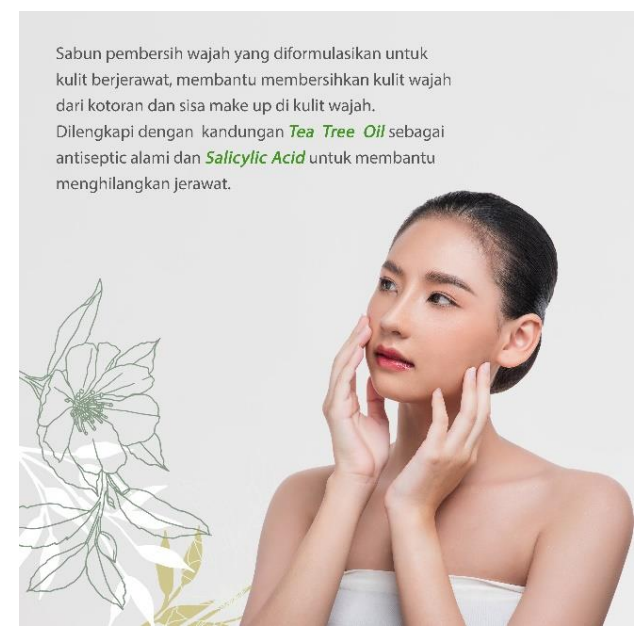

Figure 28. Product Content Veluna Facial Wash of Acne Skin

\subsubsection{Banner design}

Roll Banner Promotion Media will be needed for promotional media directly dealing with customers. The concept used is still the same as labels, packaging, website banners, and e-commerce content.

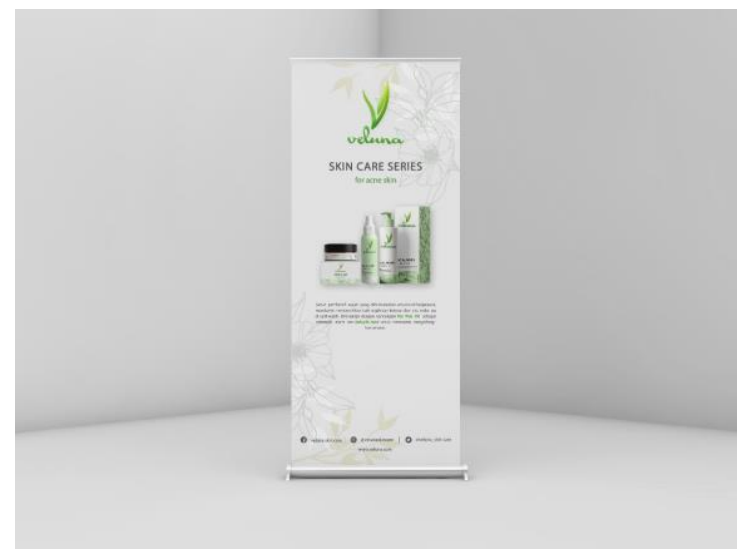

Figure 29. Roll banner Veluna skin care for acne skin

\section{Conclusion}

\subsection{Conclusion}

Through the work process in this final project, we have created a new visual identity for the skin care product "FavorLT", which is changing its name to "Veluna". In addition, logo redesign is to build an old image that is better than before through visual communication media to the general public. Through this new logo, it is hoped that the company can use it as a corporate identity and form an effective strategy to increase consumer interest in "Veluna" skin care products.

The results of the logo redesign are applied to various types, sizes and media. At first, it was applied to labels on products, then to packaging boxes, and print and e-commerce promotional media.

In general, logo redesign and its application are created as corporate identity while promoting the company to the public to get a better product image than before. In addition, a logo is a personal identity to differentiate it from others and a sign of ownership to distinguish the company owned even though it is engaged in the same field. 


\subsection{Suggestions}

1. For the company it is recommended to learn things related to marketing to attract consumers and be able to develop from existing concepts.

2. In the creative process, designers should be advised to complete the required variables when creating a visual identity in the creative process so that they get fresh ideas according to current consumer interests.

3. From the design results of this visual identity can be used by "CV. Blessindo" in terms of size, color, and shape of the existing logo as a step to improve the existing marketing strategy.

\section{References}

1. Susanto, Mikke, 2002. Diksi Rupa, Yogyakarta: Kanisius.

2. Susanto, Mikke, 2003. Membongkar Seni Rupa, Yogyakarta: Penerbit Jendela.

3. Poerwadaminta. 1997. Kamus Besar Bahasa Indonesia. Jakarta: Balai Pustaka.

4. Dinas Pendidikan dan Kebudayaan. 1990. Kamus Besar Bahasa Indonesia. Jakarta: Balai Pustaka.

5. Djelantik, A. A. M. 1996. Estetika Sebuah Pengantar. Bandung: MSPI (Masyarakat Seni Pertunjukan Indonesia).

6. Sahman, Humar. 1993. Mengenali Dunia Seni Rupa. Semarang: IKIP Semarang Press.

7. Sihombing, D. (2001). Tipografi dalam desain grafis. Gramedia Pustaka Utama.

8. Rustan, S. (2013). Font and Tipografi. Gramedia Pustaka Utama.

9. Bramantijo. (2011). Mural sebagai Tanda dan Identitas Kontemporer Kota. Panggung, 21(1).

10. Yuliawan, R. (2002). Mengenal Mural dari Waktu ke Waktu. Yogyakarta: Di Publik.

11. Farid, Rudy. (2012). Kajian Strategi Branding UNKLE 347. Wimba, 8(1), 59-81.

12. Wicandra, Obed Bima. (tt) Berkomunikasi Secara Visual Melalui Mural di Jogjakarta. fportfolio.petra.ac.id.

13. Imural, Sejarah seni mural. https://www.imural.id.

14. Umar Maulana, Perbedaan antara Karya Seni Mural dan Karya Seni Grafiti. https://busy.org/@umarmaulana.

15. Mural Papalago, Tentang Mural, https://muralpapalago.blogspot.com.

16. Rukita, Macam-macam Gaya Desain Interior. https://www.rukita.com. 